\title{
Effects of Electroformed Fe-Ni Substrate Textures on Light- trapping in Thin Film Solar Cells
}

\author{
Minsu Lee ${ }^{1}$, Jinho Ahn ${ }^{2 *}$, and Tai Hong Yim ${ }^{1 *}$ \\ ${ }^{1}$ Surface R\&D group, Korea Institute of Industrial Technology, 156 Gaetbeol-ro, Incheon, 21999, \\ Republic of Korea \\ ${ }^{2}$ Department of Materials Science and Engineering, Hanyang University, Seoul, 04763, Republic of \\ Korea \\ *E-mail: thyim@kitech.re.kr, jhahn@ hanyang.ac.kr
}

doi: $10.20964 / 2018.06 .27$

Received: 23 February 2018 / Accepted: 5 April 2018 / Published: 10 May 2018

\begin{abstract}
Electroforming can be used to separate electrodeposited metal from the surface of a metal or other conductive material to produce new metallic products with fine shapes. Because Si thin-film solar cells possess fewer absorption layers than other compound thin-film solar cells, light-trapping technology is required to increase the rate of light absorption. Various metal substrate shapes can be constructed in the electroforming process, depending on the shape of the mandrel surface. The objective of this study was to construct specific textured substrates through electroforming to improve light-trapping efficiency in silicon ( $\mathrm{Si}$ ) thin-film solar cells. We constructed pyramid- and V-shaped substrates at angles of $30^{\circ}, 45^{\circ}$, and $60^{\circ}$ by electroforming. To observe the reflective properties of the manufactured substrates, we used an ultraviolet/visible (UV/Vis) spectrometer to measure the total and diffused reflectance. We found that an increase in the contact angle due to changing texture led to a decrease in total reflectance in Fe-Ni alloy substrates. We concluded that substrate texture led to an increase in the light paths in the light-absorbing layers of the thin-film solar cells.
\end{abstract}

Keywords: Electroforming, Fe-Ni alloy, Light-trapping, Textured substrate, Thin film solar cell

\section{$\underline{\text { FULL TEXT }}$}

(C) 2018 The Authors. Published by ESG (www.electrochemsci.org). This article is an open access article distributed under the terms and conditions of the Creative Commons Attribution license (http://creativecommons.org/licenses/by/4.0/). 